REINEKE, Martha University of Northern lowa

@ martha.reineke@uni.edu

\title{
Rivalry, affect, and religiously inspired violence: a critique of René Girard and Jonathan Sacks
}

\author{
Rivalidad, afecto y violencia inspirada por la religión: \\ una crítica de René Girard y Jonathan Sacks
}

\begin{abstract}
A pressing issue of our day -religiously inspired violence in places where Judaism, Christianity, and Islam are dominant faiths- is an ideal focal point for considering psychoanalysis in relation to mimetic theory. Rabbi Jonathan Sacks' book Not in God's Name: Confronting Religious Violence (Sacks, 2017) proves highly instructive in the context of such an exploration. In his perspicacious application of Girard, Sacks distills the significance of mimetic theory for understanding religiously inspired violence.
\end{abstract}

KEY WORDS: Rivalry, affection, violence.

Un tema apremiante de nuestro día, la violencia inspirada de manera religiosa en lugares donde el judaísmo, el cristianismo y el islam son creencias dominantes, es un punto focal ideal para considerar el psicoanálisis en relación con la teoría mimética. El libro del Rabino Jonathan Sacks No en nombre de Dios: cómo enfrentar la violencia religiosa (Sacks, 2017) es altamente instructivo en el contexto de tal exploración. En su aplicación perspicaz de Girard, Sacks destila el significado de la teoría mimética para comprender la violencia de inspiración religiosa.

PALABRAS CLAVE: Rivalidad, afecto, violencia.

Contemporary psychoanalysis is increasingly attentive to a wide range of social phenomena as well as to the role of imitation in human relationships, embracing notions of intersubjectivity remarkably similar to those of René Girard. Yet Girard and his successors in the field of mimetic theory have all but ignored psychoanalysis as a resource for assessing how intimate dimensions of our lives impact our actions in an increasingly unstable society. In this essay, I redress this oversight, highlighting intimate features of human experience to which psychoanalysis attends while also emphasizing ways in which psychoanalysis illuminates violence in a social context -a setting that Girard investigated with compelling results. 
A pressing issue of our day -religiously inspired violence in places where Judaism, Christianity, and Islam are dominant faiths- is an ideal focal point for considering psychoanalysis in relation to mimetic theory. Rabbi Jonathan Sacks' book Not in God's Name: Confronting Religious Violence (Sacks, 2017) proves highly instructive in the context of such an exploration. In his perspicacious application of Girard, Sacks distills the significance of mimetic theory for understanding religiously inspired violence. As a consequence, Sacks demonstrates that Girard's insights are ever timelier. Yet even as Sacks also acknowledges Freud as a key intellectual resource, Sacks largely leaves Freud behind, as has Girard before him. Attending to psychoanalysis as Sacks and Girard have not, I make the case for enhanced engagement by mimetic theory with psychoanalysis. Examining religiously inspired violence, I show that mimetic theory and psychoanalysis are complementary resources for addressing this issue.

I take psychoanalysis to be a more compelling tool for analyzing violence than did Girard. Throughout his career, Girard remained wary of psychoanalysis. Girard acknowledged that he shared with Freud the goal of uncovering a universal mechanism to account for desire; however, Girard claimed that Freud's candidate for the mechanism of desire -the Oedipal triangle-cannot explain its dynamics. As Mark Anspach (2004) states, «Freud's Oedipus is forever bound to a primordial object, the mother, and a primordial rival, the father; later relationships perpetually re-enact, for better or worse, this original triangle». Wishing to free the mechanism of desire from these Freudian constraints, Girard argued that «The mimetic process detaches desire from any predetermined object» (Girard, 1979). For Girard, desire is «'utterly open-ended'» (Anspach, 2004). I contend that Girard misconstrued one of Freud's primary aims: to discover how desire is borne by a body. Freud's attention was drawn, in particular, to wounded desire that is registered as trauma. Freud's vision, as expansive as Girard's, homed in on early familial experiences not so much in order to conceive of adult relationships as replays of early encounters with mommy and daddy but in order to explore how early relationships persist in later life in the form of embodied imprints. For Freud as for Girard, desire is open-ended and subject to infinite variety; nevertheless, for better or worse, our bodies bear the history, not only of our early experiences with desire, but also of experiences across our lifetimes, including trauma and violence. By focusing on how psychoanalysis addresses what Girard neglects in the history of desire embodiment- I confirm that psychoanalysis can enhance mimetic theory, specifically in application to Sacks' Girard-influenced account of religiously inspired violence. Interestingly, Girard models the dialogue I seek between psychoanalysis and mimetic theory when, in two uncommonly affirmative statements, Girard acknowledges that Freud's texts «support and validate mimetic theory» (Girard, Antonello, \& Rocha, 2007) and issues an invitation for «a conversation of equals» (Girard, 2008).

\section{A pathology of Violence}

Sacks employs Girard's mimetic theory to identify a pathology of violence in which the Abrahamic faiths of Judaism, Christianity, and Islam are implicated. Mimetic theory promises to explain how fear becomes hate and how hate leads to violence. Sacks identifies three features in this sequence. First, a dualistic mindset is acquired. Second, myths feed and secure one's capacity to experience the world dualistically. Finally, sibling rivalry develops 
(Sacks, 2017). Indeed, a defining factor of the religiously inspired violence that besets the Abrahamic faiths is sibling rivalry» (Sacks, 2017).

Sacks (2017) defines dualism as what happens when «cognitive dissonance between the way things are and the way one wants things to be becomes too great». In its religious manifestation, this dualism features in responses to the challenge of theodicy. When bad things happen to good people, one preserves the goodness of God at the cost of separating an evil force from God. Pathological dualism, described by Sacks as a mutation in theological dualism, does to people what theological dualism has done to God. Sacks (2017) recognizes three features in this pathological dualism. One creates and dehumanizes enemies, dividing the world into in and out groups. Further, one sees oneself as a victim and actions taken against others as gestures of self-defense. Finally, one kills in the name of God.

Sacks points out that theological dualism does not always coexist with pathological dualism. For example, the ancient communities at Qumran and Nag Hammadi were dualist but not violent (Sacks, 2017). Instead, theological dualism changes into pathological dualism when a group begins to enforce order in the face of conflict via a tit-for-tat cycle of revenge. The group eventually finds itself focusing on a third party as the cause of their troubles, realizing through trial and error that, when they do so, they break what previously has been a never-ending cycle of revenge. When they banish from their midst or kill that third party, the violence by which they have been beset ends, and pathological dualism reaches its full realization. Thus, Sacks (2017) takes directly from Girard his understanding of how dualism becomes a malignant social process. Mimetic rivalry leads to scapegoating, and the scapegoat mechanism, a generator of peace, gives birth to the sacred and to sacrificial religion.

\subsection{Antisemitism: a case study in pathological violence}

Sacks applies his Girardian analysis to antisemitism, especially in its recent manifestations in predominantly Muslim countries. He lists themes in Muslim media attacks on Jews: Jews participate in a global conspiracy; they partake of human flesh during Passover; they are responsible for faking the Holocaust and for plotting 9/11 (Sacks, 2017). Skeptical that the source of hatred visible in these accusations is the current conflict between Israel and Palestinians, Sacks finds in an historical comparison a more likely cause. In Germany in the 1930s, Jews comprised one percent of the German population; among the fifty-six nations that currently comprise the Organization of Islamic Co-operation, Jews constitute a minute percentage of the population (e.g., two percent in Egypt, Jordan, and Pakistan). Sacks surmises that Jews' minority status in the 1930s and today is linked with the anti-Semitic claim that Jews are a dangerous force. Fear is born of a paradox: a defenseless group secretly harbors great power. Then as now, additional contradictions abound: Jews are too rich and too poor, global capitalists and communists, controllers of the United States and Russia, reclusive and infiltrating outsiders, primitive and cosmopolitan (Sacks, 2017). From the midst of these conflicting claims wells up a desire to annihilate Jews. Sacks (2017) wants us to recognize that Islamic antisemitism is new. Sacks claims that a call among some Muslims for the destruction of Jews is a recent pathological permutation of previously episodic xenophobia. Asserting that the dualism evident in accusations leveled against Jews is a key symptom of this pathology, 
Sacks employs Girard's mimetic theory to set the contradictions of antisemitism in the context of scapegoating.

According to Girard, scapegoating is a mechanism of persecution that emerges when two groups, beset by conflict, center their attention on a third party, an outsider to their strife, who is deemed wholly responsible for the conflict and is not powerful enough to retaliate (Girard, 1986). Plausibility is essential. A third party too close to the contending groups will lack necessary substitutionary capabilities; one too far away will stymy the accusers' efforts to trace the source of their problems to that party's door. The third party to be scapegoated may be an individual or a group. Dualistic renderings are symptomatic of the ideal scapegoat: viewed through that liminal lens, the scapegoat seemingly occupies both sides of a perceived threat, positioning it to fulfill its lethal and salvific role. Jews -outsiders who are also neighbors and to whom are ascribed the contradictory traits Sacks has documented- have been ideal scapegoats in European history. As Sacks (2017) argues, «wherever you find obsessive, irrational, murderous antisemitism, there you will find a culture so internally split and fractured that if its members stopped killing Jews they would start killing one another».

Sacks offers several examples. In 1095, Christian crusaders on their way to liberate Jerusalem from Muslims massacred Jews in communities across northern Europe. Jews' scapegoat credentials were established then. Constituting a demonic and destructive force, Jews posed a deadly threat. They were said to poison wells, spread the plague, and cannibalize Christian children. Both the persecution of Jews in Spain culminating with the 1492 expulsion and Luther's 1543 pamphlet On the Jews and their Lies, a manifesto of hate, laid groundwork for future Jewish scapegoating. That Enlightenment philosophers added to this trajectory of antisemitism, paving the way for the Nazis, is a «little-known phenomenon but a devastating one» (Sacks, 2017). In each cultural moment, Jews were outsiders to conflicts between other powers: e.g., the Great Schism between the Western and Eastern branches of Christianity, the punitive Treaty of Versailles, and the fall of the Ottoman Empire in 1924. Post-colonial nationbuilding in the Middle East, with associated Shia and Sunni Muslim tensions, makes this region vulnerable to conflict today. Even so, the role Israel plays in current geopolitics is insufficient, from Sacks' perspective, to account fully for the virulent hatred directed against Jews by some Muslims (Sacks, 2017).

Sacks draws on Girard's concepts of mimetic desire and rivalry to shed additional light on causal factors associated with antisemitism, yesterday and today. Girard observes that mimetic desire, which structures intersubjective relations, is inherently unstable: when we mirror each other, each of us seeks a fullness of being in the other that, by virtue of our human condition, all of us lack (Girard, 1979). Desires and the rivalries that ensue in the face of lack characterize not only our relationships with family, friends, and colleagues but also our interactions with groups defined by culture, religion, or nation. When competition breaks out among groups, conflict can be especially intense. Not only is the satisfaction of desire -acquisition of land, resources, power- more difficult in competitions among large groups but also the existential/ ontological threat of non-being, which drives desire, is more intense when groups back their competing aims with weapons of war. According to Girard (1979), as tensions rise, an increasing undifferentiation among groups who mirror each other results in their monstrous doubling, fueling the perception that each group poses a mortal threat to the other and making it increasingly likely that one of the rival groups -or a scapegoat substitute-will be attacked. 
Sacks insightfully applies Girard's schema of monstrous doubling to illuminate the history of antisemitism. Just as Girard locates in myths testimony to mimeticized violence, so also does Sacks observe that two myths have played a dominant role in the production of antisemitic hatred and violence. ${ }^{[1]}$ The first of these is the myth of «Blood Libel». As described by Sacks (2017), in 1144 in Norwich a stabbing occurred in which a child named William died. Jews were rumored to be responsible, but no action followed. Five years later, Thomas of Monmouth, a monk, wrote an account of the event in which he claimed that Jews kill Christian children and use their blood to make matza for Passover. Although several popes made specific pronouncements condemning the myth, it persisted. Over time, more than 150 cases, some of which were associated with massacres of Jews, were recorded (Sacks, 2017). The second mythic account of Jews that Sacks describes is preserved in The Protocols of the Elders of Zion. Written by Russian secret police, the document purports to be minutes of secret Jewish conspiracy to achieve world domination by controlling all media and every economy. A forgery with no credible historical value, The Protocols was read widely and played a key role in Nazi propaganda (Sacks, 2017).

Dualistic splitting and projection give these two myths their profound appeal. Whereas kashrut (Jewish food law) renders any food with even a speck of blood inedible, the Christian belief in transubstantiation -the bread and wine of the Eucharist transform into the body and blood of Christ- brings the consumption of blood into the center of the Christian belief system. I Indeed, the term «transubstantiation» first appears in the Christian lexicon in 1079 and becomes Christian doctrine inn 1215 during the Fourth Lateran Council, a time that encompasses the origin and development of the myth of Blood Libel (Sacks, 2017). The early years of the promulgation of the myth coincided with a period of unrest in England that followed the Norman Conquest and included the Crusades. Projection, in service to the monstrous doubling that drives scapegoating, functioned powerfully within this unstable social context. The myth captured threats and pinpointed Jews as the responsible party. So also do these psychological processes feature in The Protocols. It was written between 1881-1882 at the height of pogroms against Jews in Eastern Europe that turned millions into homeless refugees. Wholly vulnerable and powerless, Jews mirrored the desires of the fabricators of The Protocols: proponents of Russian imperialism with yearnings for greater political power. Their dreams would be vanquished in the revolutions of 1905 and 1917 (Sacks, 2017). In the case of both myths, Girard's theory provides the explanatory mechanism. First, social unrest produces a need for a scapegoat. Subsequently, projection creates a proximate connection with a blameworthy victim: vulnerable Jews. Mirror-work by this Jewish other, who is neither too close nor too far from the communities in crisis to be cast as blameless, make the Jew a monstrous double who, when banished or killed, is perceived to rid the community of what has threatened it, ending the social crisis.

Sacks emphasizes that these myths are highly relevant to analyses of contemporary antisemitism in the Middle East. Christians introduced the Blood Libel myth in various cities throughout the Middle East in the nineteenth century. In 1840 in Damascus, a localized variant of the myth emerged when a Capuchin monk disappeared and Jews were accused of killing him in order to use his blood in their rituals. In 1983, Mustapha Tlass, the Syrian defense minister, wrote The Matza of Zion, which purported to confirm the historical veracity of the «Damascus Blood Libel». Translated into English and reprinted several times, The Matza of 
Zion has played an instrumental role in antisemitism in the Middle East (Sacks, 2017). The Protocols of the Elders of Zion appeared in Arabic translation in the 1930s and has been reprinted as well as widely sold and read in the Middle East. A 2002 multi-part television dramatization of The Protocols was produced and shown in Lebanon, and a similar series appeared on Syrian television in 2003. Statements of belief in a Jewish conspiracy for world domination have been noted in documents of various Middle Eastern political groups. Drawing on these longstanding myths, individuals in predominantly Muslim countries have written a new chapter in the history of scapegoating antisemitism (Sacks, 2017).

Throughout, whether he is analyzing that history among Christians or Muslims, Sacks grounds his explanations in Girard's mimetic theory. In a time of social crisis, «a victim -an individual or group- is turned into a scapegoat as a way of projecting outwards the violence that would otherwise destroy a society from within» (Sacks, 2017). Mimeticism, a key feature of human behavior, becomes ossified in dualism, and that dualism becomes pathologically lethal when a group feels endangered. The mechanism works, thanks to a fatal transition humans make from one existential question to another: «Why is there social disorder?» is replaced by «Who did this to me?» According to Sacks (2017), in a final segue, a scapegoatseeking question is asked: «Who is to blame?»

\subsection{Sibling rivalry: solving the puzzle of religiously-inspired violence}

Sacks points out that features of pathological violence he has analyzed using categories of mimetic theory are applicable to his test case of antisemitism but have no unique connection to Judaism, Christianity, or Islam. He could have selected other historical examples of dualism and projection in his exploration of scapegoating. The decisive factor that reveals the source of the distinctively fraught relationships among the three Abrahamic faiths lies elsewhere -with sibling rivalry.

Girard proves extraordinarily insightful for Sacks because sibling relationships are paradigmatic for Girard of mimetic rivalry. Girard cites fraternal relationships in myth and history -Cain and Abel, Eteocles and Polyneices, Romulus and Remus- that demonstrate the proliferation of enemy brothers whose fraternal violence presages cultural violence (Girard, 1979). Where most theorists of violence attribute hatred to the difference others pose for us, Girard understands that animosity among siblings is linked to sameness. ${ }^{[2]}$ Indeed, Girard's most striking contribution to analyses of violence is that the motor of accelerating violence is always humans' similarities to each other. Similarity rather than difference provokes a sense of escalating threat that issues in aggression (Girard, 1986). And, indeed, similarities link the three Abrahamic faiths, sustaining their relationships with each other across the centuries and also accounting for moments of conflict between them.

The sibling metaphor is especially apt for Sacks' reflections on the Abrahamic faiths. Sacks reminds his readers of what siblings do. A child receives a new toy; suddenly, its sibling wants to play with the toy even though the sibling previously has evinced no interest in it. Importantly, the sibling's interest, in all truth, is not directed toward the toy. The sibling is not interested in having what the other child has so much as it is attracted to being what the other child is, namely, someone on whom an adult, by means of the toy, has bestowed love and recognition. In this way, 
siblings at play show how humans take ontological purchase on the objects of our desire (Sacks, 2017). The sibling analogy fits the Abrahamic faiths. After all, they share the same God, and many of the same figures feature in their sacred texts -Adam and Eve, Noah, Moses, Jesuseven as these three faiths experience intense rivalries. Writes Sacks of this rivalry:

At the heart of all three faiths is the idea that within humanity there is one privileged positon -favoured son, chosen people, guardian of the truth, gatekeeper of salvation- for which more than one candidate competes. The result is conflict of the most existential kind, for what is at stake is the most precious gift of all: God's paternal love (Sacks, 2017).

Humankind's defining feature -mimetic desire- becomes tragically implicated in the history of Judaism, Christianity, and Islam whenever its primary characteristic -rivalry- distorts relationships adherents of the three faiths have with God and with each other. The sacred texts of all three groups preserve elements of this history.

For example, sibling rivalry engages Jews and followers of Jesus before there is a fullydefined religion of Christianity. Prior to the writing of the Gospels and long before the New Testament canon was compiled, followers of Jesus debated with their fellow Jews in the synagogue whether Jesus was the future of Judaism. With the Jewish people under assault by Rome, internal divisions among Jews (Sadducees, Pharisees, and Essenes) also complicated the picture (Sacks, 2017). Into this complex and charged environment stepped Paul, a Jew and a follower of Jesus who challenged the notion that Jesus' mission was primarily to Jews and that anyone who wished to follow Jesus must also be an observant Jew who would keep Jewish laws, including kashrut, circumcision, and Shabbat (the Sabbath). Paul introduced the sibling metaphor in Galatians, one of the earliest writings of the nascent Christian faith. Paul recalls that Abraham had two sons: one by a slave and one by a free woman. Ishmael, the child of the slave Hagar, institutes a legacy of slavery for his successors; however, Isaac initiates a covenant of promise and freedom to be realized only among followers of Jesus (Sacks, 2017).

Paul amplifies the symbolism of the sibling metaphor in his letter to the Romans when he excludes Jews from covenantal relationship with God. Paul writes (Romans 9:6), «For not all who are descended from Israel are Israel. Nor because they are his descendants are they all Abraham's children. On the contrary, "It is through Isaac that your offspring will be reckoned"» (Sacks, 2017). Although Abraham is the biological father of Isaac and Ishmael, only Isaac persists in a special relationship with God. Only Isaac is gifted with God's promise. A few verses later, Paul is blunter. Isaac's daughter, Rebekah, gives birth to twins. However, before they are born God has excluded one of the twins from relationship with God. Paul writes (Romans 9:13): «'Jacob I loved, but Esau I hated'» (Sacks, 2017). Jacob is heir to Abraham's covenant; Esau is not.

Reversing and disavowing Jewish self-understanding in his effort to speak to Jews who are followers of Jesus, specifically, Christian Judaizers, Paul succeeded with his sibling metaphor in carving out inclusive terms for Christian identity but at tremendous cost. As Christianity developed as a religion in Asia Minor, dominated more and more by converts largely unfamiliar with the internal conflicts that had beset the first-century synagogue and had inspired Paul to coin the sibling metaphor, Paul's words were taken up as a weapon against Jews. Sacks 
(2017) explains how the Church Fathers likened Jews to Cain, who murdered his brother. Akin to Cain, Jews of the Diaspora could justifiably be condemned to wander in exile forever. This analogy was used to justify the expulsion of Jews from their countries of residence between 1290 and 1492. And the Church Fathers embraced other familial metaphors to problematically distinguish Christianity from Judaism. For Cyprian, Jacob's wife Leah has weak eyes. Her view of God is veiled and she represents «'a type of the synagogue'». Rachel, Jacob's beautiful and clear-eyed younger wife, is «'the type of the church'» (Sacks, 2017). In Medieval Europe, Cyprian's familial analogy is depicted in sculptures, tapestries, and paintings that adorn cathedrals: The Church and the Synagogue are portrayed as two wives. Because these images contrast the beauty and triumph of the Christian wife with the blindness and failure of the Jewish wife, they are implicated in the production of European antisemitism (Sacks, 2017).

Two centuries after Paul deployed the metaphor of sibling rivalry to describe tensions between Jews who followed Jesus and those who did not, Islam took up the sibling metaphor and reversed it: Abrahamic succession for Muslims would pass through Ishmael, not Isaac (Sacks, 2017). But Sacks does not discuss that reversal. Not wanting to exacerbate mimetic rivalries, he will not cast a vote for most and least problematic uses of the sibling metaphor. That Sacks is at pains not to promote the very rivalries he wants to disarm is evident when he points out that a competition for «'most favoured faith in the eyes of Abraham's God'» did not begin with the Christian Paul (Sacks, 2017). After all, intrafaith competition already pervades the Hebrew Bible from its first pages. The question of God's favorites -Isaac or Ishmael, Jacob or Esau, Joseph or his brothers- is taken up in Genesis. Long before Christianity and Islam join the Abrahamic family of faiths, violence shadowed these siblings. Nevertheless, as Genesis concludes, violence is countered with stories that attest to a God who undermines and subverts rivalries. This God declares, «Not in My Name» (Sacks, 2017).

\section{SubVerting VIOLENCE: ETHICS AND INTERTEXTUALITY}

Sacks (2017) offers recommendations for breaking the hold malignant rivalries have on human society. He believes that dualism, fatefully emerging whenever humans cease posing the question «Why did this happen?» and start asking «Who did this to me?» can be challenged when we ask a new question: «What shall I do?» Sacks identifies two guides for action: instructive texts and inspiring leaders.

Citing the sacred texts of the Abrahamic faiths, especially the Hebrew Bible, Sacks (2017) demonstrates that, throughout history, a counter-narrative to dualism is visible that embraces rather than accuses the other. Sacks says that sacrificial stories can absorb and transform each other. When this happens, stories of peace challenge readings that promote violence. By contrast, he labels stories that perpetuate theological and pathological dualisms as «fundamentalist». Five stories from Genesis serve as examples, in respect to which Sacks shares three findings. Sacks' first finding is this: a mythic dualism that would justify scapegoating is absent from all five stories. In these narratives, individuals are neither completely good nor hopelessly lost; rather, "The best have their faults. The worst have their virtues» (Sacks, 2017). As a consequence, in the wake of Abel's murder by his brother Cain, alternatives can be imagined to sibling rivalry. With his second finding, Sacks maintains that readers have no 
single point of reference on these sibling stories. Readers are prevented by the stories themselves from choosing sides and identifying exclusively with one party to a conflict. Inviting our immersion in their themes, the texts prompt us also to assume a stance of questioning attentiveness as we read (Sacks, 2017).

So focused, we can be instructed by the stories. In the second story, Isaac and Ishmael's conflict with each other over favored status with their father concludes with a scene utterly different from that with which the story of Cain and Abel ends. Isaac and Ishmael stand at their father's grave in silent testimony to reconciliation. Jacob and Esau's story offers an even more detailed account of the maturation of sibling rivalry into mutual acceptance. In the fourth story, Joseph and his brothers participate in a process of reconciliation that becomes definitive for all future relationships. ${ }^{[3]}$ Joseph, as the story goes, is the firstborn of Rachel and Jacob. He is Jacob's favorite, and Joseph's ten brothers are jealous. They plot his death and eventually have him sold into slavery in Egypt. His fortunes improve eventually and, as vizier to the pharaoh, he oversees the storage of surplus grain. In the midst of famine, Joseph's brothers travel to Egypt to buy some of this grain. They do not recognize Joseph; however, he recognizes them and constructs an elaborate plot to force his brothers to replicate in their own lives the trauma of scapegoating they perpetrated against him, this time with their youngest brother, Benjamin, as victim. In the denouement of this familial drama, Joseph's reconciliation with his brothers replaces retribution. Judah, the brother who had proposed selling Joseph into slavery so many years before, is appalled by the prospect of Benjamin meeting the same fate. Newly aware of the harm done to Joseph by his siblings, Judah repents, opening a way to the transformation of the other brothers. Joseph's declaration to his brothers - «'You intended to harm me, but God intended it for good'»-, shows that «I win, you lose» rivalry is not the last word on the human condition (Sacks, 2017). Finally, a fifth story features Moses, Aaron and Miriam. Rivalries are absent from their relationships: Miriam watches over Moses, and Aaron acts as Moses' spokesman. These siblings reconfirm what the story of Joseph and his brothers has demonstrated: rivalries can be replaced by mutually supportive relationships (Sacks, 2017).

The message of Genesis is clear: sibling rivalry is real and poses serious risks; however, it is not inevitable. The cumulative impact of the five stories featured in Sacks' discussion generates his third finding. Humans are capable of identifying with previous rivals in new ways. We are not condemned to everlastingly flip the roles of victim and victimizer; rather, our rivalries can be neutralized. With a change of heart (teshuvah), we can stand in the shoes of Joseph and his brothers. Identifying with victims of rivalry, we can answer in the affirmative the question initially posed by Cain: Yes, we are our brother and sister's keeper (Sacks, 2017). An ethics of plenitude can replace an ethics of scarcity and scapegoating.

For Sacks, intertextuality accounts for how the Genesis stories lead to personal transformation. Sacks acknowledges Julia Kristeva for coining the term, which he cites as one of the Hebrew Bible's most striking features. For Sacks, intertextuality describes a compositional structure in which «the meaning of a word here may lie in that word there, far separate in topic and time» (Sacks, 2017). In this way, the five stories Sacks highlights form an intertextual arc across the pages of the Hebrew Bible that readers can follow to the point of their own transformation. ${ }^{[4]}$ Sacks does not cite Girard as an influence on his reflections on intertextuality; nevertheless, Girard echoes Sacks when he talks about great literature. Girard suggests that such literature invokes in microcosm the vicissitudes of mimesis that we struggle to comprehend 
in our larger world, bringing them into the uncomfortable light of day. But great literature also opens the way to a different existence when «deception gives way to truth, anguish to remembrance, agitation to repose, and hatred to love» (Girard, 1965). Sacks can be understood to affirm Girard when he describes teshuvah as a reversal in identification that nullifies rivalry and opens the door to compassion (Sacks, 2017). Girard would concur that texts tutor their readers in acts of transformation: «In reading, we relive the spiritual experience whose form is that of the novel itself» (Girard, 1965). Girard's words also appear to describe the extraordinary intertextuality of the Hebrew Bible.

In addition to recommending the Hebrew Bible as a resource for dismantling violent rivalries, Sacks offers a second guide for action. He calls for a new generation of religious leaders and educators who will help us win the peace (Sacks, 2017). These individuals will oversee efforts to counter «the teaching and preaching of hate». Drawing on features of the Abrahamic faiths that promote concern for others, they will acquaint persons with principles of justice and compassion and teach us to embrace rather than fear neighbors and strangers. They also will teach conflict resolution and help individuals develop listening skills that promote empathy and understanding (Sacks, 2017). These leaders will arouse our admiration and inspire nonrivalrous imitation. Sacks' appeal to religious leaders and educators is reminiscent of Girard's call for models of "external mediation». ${ }^{[5]}$ These persons are exemplars from whom we feel sufficiently distant that we can safely emulate them without becoming rivals. They are models of positive rather than acquisitive mimesis. ${ }^{[6]}$

Sacks' suggestion that instructive texts and inspiring leaders can counter pathological violence is intriguing; nevertheless, it also makes visible limits Girard's mimetic theory places on Sacks' vision. Missing from Sacks' appropriation of Kristeva's concept of intertextuality are two features critical to Kristeva's own definition. For Kristeva, intertextuality is a signifying process of a speaking being (Julia Kristeva, 1975). Intertextuality, from Kristeva's perspective, refers to how meaning passes from one sign system to other sign systems. Calling this move «transposition», she conceives of meaning transpiring on a field in which objects of desire and the human subjects who enunciate that desire experience dislocation in being (Kristeva, 1984). Always in process, humans' signifying practices have multiple origins and paths of development: visual, tactile, acoustic, and kinesthetic (Kristeva, 1982). Before humans acquire language, intertextuality emerges in young children's gestures and babbling, which establish an arc of meaning that emerges out of and crosses through the body on the way to language. Intertextuality tethers human beings always to the embodied nexus of our origins.

Because Sacks and Girard do not see that intertextuality applies not only to texts but also to processes -gestures, sounds, rhythms- that predate language, they do not adequately analyze how embodiment features in religiously inspired violence and its alternatives. Moreover, both are remarkably circumspect on what galvanizes persons to set out on a path to positive mimesis. Employing innumerable examples from literature, history, and anthropology, Girard offers detailed accounts of mimetic rivals beset by conflict. Yet he has little to say about positive mimesis, and he most often describes transformed individuals as wholly passive recipients of grace. Exploring «the power that triumphs over mimetic violence», Girard (2001) asserts simply that «the Spirit of God possesses them and does not let them go". With his call to build a cohort of leaders for peace, Sacks largely bypasses the question of how the teachings of these leaders will prove compelling to followers, transforming them into agents for peace. 
Given the central influence of Girard on his work, that Sacks' two-part solution to religiously inspired violence is less robust than his analysis of its causes is not surprising. Sacks (2017) asserts that «wars are won by weapons, but it takes ideas to win a peace». But Sacks does not go far enough. If the idea of peace is to take root, intertextuality needs extended application. We need not only to open our minds to the idea of peace but also to reposition our bodies to act for peace. ${ }^{[7]}$ So also should our models of non-rivalrous interaction empower us in the embodied dynamics of teshuvah, altering our entire being rather than transforming only our thoughts. Turning to psychoanalysis, I demonstrate how Girard and Sacks' explorations of violence can benefit from a perspective that finds on a more intimate terrain vital resources for the transformation Sacks and Girard seek.

\section{A BOUNDARY PSYCHOLOGY}

Let's consider a boundary psychology overlooked by both thinkers that is active among individuals beset by hate whose fears of contamination precipitate acts of ethnic cleansing and other violence. This psychology is rooted in embodied experience and present in affect. As Kristeva (1982) recounts in Powers of Horror, a formidable lexicon of disgust features in intertextual practices inclusive of the body. When we demonize others who we experience as threatening, our mouths twist in disgust, as if to spit them out in order to protect ourselves from contamination. Visceral acts and gestures contribute to the patterns of violence that Sacks seeks to counter. To break these acts' hold on us and make peace, we must be able to embody peace and not merely think about it.

If we are to advance this goal, we must reconceive fundamentalism, on which Sacks focuses his criticisms of religiously inspired violence. Sacks (2017) claims that fundamentalism is major source of that violence because it combines religious and pathological dualisms. $\mathrm{He}$ observes that fundamentalism arises when there is «dissonance between the world of tradition and the secular domain». A form of dualism, fundamentalism has particular potential to evolve into apocalyptic violence. Drawing on literalist readings of sacred texts, fundamentalism emerges because «the world has been allowed to defeat the word» (Sacks, 2017). According to Sacks (2017), the cure for fundamentalism is three-fold: Deploy a non-literal hermeneutics to read texts; engage in reasoned arguments to understand them; and nurture an active religious imagination that empowers us to interpret words with love. Dualism -the proclivity for strong in/out group designations- does feature in fundamentalism; however, Sacks believes the literal reading of sacred texts drives the pathology behind in/out group mentalities. He writes, «The sacred literatures of Judaism, Christianity, and Islam all contain passages that, read literally, are capable of leading to violence and hate» (Sacks, 2017).

Sacks' argument is not entirely persuasive. He does not explain how persons become attracted to fundamentalist readings of texts that bolster a dualistic mentality with potential for pathological expression. James Jones' Blood that Cries out From the Earth: The Psychology of Religious Terrorism (2008) offers a more nuanced discussion of fundamentalism that illuminates affective markers decisive to its power. Jones looks not only at Muslim jihadism, but also at manifestations of fundamentalism in Aum Shinrikyo, which has roots in Japanese Buddhism, and at American apocalyptic Christianity. Like Sacks, Jones (2008) 
draws on Girard to describe a scapegoat mechanism that features in religious violence. So also does he attribute a proclivity for violence to dualism. On one side of this duality may be found secularization, decadence, immorality, evil, and unrighteousness; on the other side stands a community immersed in eternal values such as goodness, righteousness, and purity. Jones (2008) suggests that mimetic desire maintains dualism, attends efforts to monitor and enforce ethnic, gendered, and religious boundaries, and features in social conflicts. However, in contrast to Sacks, who attributes violence to the influence of a fundamentalist hermeneutics, Jones explores psychological processes through which individuals become committed to the notion that texts are infallible. Moreover, echoing Sacks' interest in the role leaders play in challenging religiously inspired violence, Jones establishes how adherents to fundamentalism extend to their leaders their commitment to abide by the unerring truth of their guiding texts, granting these individuals unquestioned authority as well. By focusing on fundamentalists' posture of fidelity to leaders and not only to texts, Jones more directly ties religiously inspired violence to the pathological dualism that both Sacks and he make central to their analyses. Values and perceptions grounded in affect feature prominently in Jones' account. Yes, apocalyptic beliefs of fundamentalism describe a cosmic struggle against a demonized other. However, adherents do not appeal to violence because of these ideas; rather, they become violent because they perceive their very bodies to be under imminent threat. The pure and good, under threat by the impure and evil, must actively be protected from assault.

Jones uncovers several psychological processes common to fundamentalist groups that make them vulnerable to promoting religiously inspired violence. Dualism is taken up by Jones as one of these processes. The religious quest -a search for personal meaning and transformation- is subsumed among fundamentalists by a «Manichean dichotomizing of the world into all-good, all evil camps» (Jones, 2008). Further, adherents pursue this quest with a view to appeasing «a humiliating or persecuting idealized patriarchal Other». In the face of these psychological preconditions, religious texts and religious leaders play an important role in promoting believers' propensity for religiously inspired violence. Key warning signs include splitting processes visible in texts that demonize a wholly evil other and practices that compel submission to a «wrathful, punitive idealized deity or leader» (Jones, 2008). Both of these factors are visible in American apocalyptic Christianity.

American Christianity is exceptionally diverse, and Jones narrows his focus to participants in a single strand of Protestant Christianity: evangelicals who subscribe to a «rapture theology». A twelve-volume series of popular novels collectively titled the Left Behind series illuminate this theology. These books are interpreted by believers in rapture theology as step-by-step accounts of how apocalyptic events will bring this world to a violent, bloody end. More than sixty-five million copies of books in the Left Behind series have been sold, netting their Christian publisher, Tyndale House, more than $\$ 650$ million in revenue. A survey found that nineteen percent of Americans have read the Left Behind books. As the series title suggests, the books play on fears of abandonment and disconnection from others that periodically beset individuals. In setting these emotions within the context of an apocalypse, the Left Behind series has the potential to create intense anxiety among believers in rapture theology. With anticipatory dread, they fear being separated from family members, friends, and their community of faith if they are left behind when the rapture happens and the world as we know it ends. 
A splitting process that demonizes an evil other is visible in the Left Behind series in book passages that describe the rapture. The saved receive the mark of Christ on their forehead; the unsaved bear the mark of the beast (Jones, 2008). Because difference is sacralized, a framework is put in place in which adherents claim their salvation and the same moment designate nonbelievers as lost and abandoned. Psychologically, this immediate and intimate juxtaposition of in and out groups contributes to the «social death» of everyone who falls outside the believers' world, making future accommodation to actual social violence more acceptable (Jones, 2008). Political events, wars, and natural disasters -floods, earthquakes, hurricanes- are fed into this narrative, securing believers' sense of their own safety and flattening their affective responses to others' trauma (Jones, 2008). In turn, decreasing levels of empathy prepare believers to offer a sanguine response to the extreme violence that will kill untold numbers in the apocalypse, with a potential corresponding deadening of concern for mass death in their world today.

Submission to a wrathful, punitive idealized deity or leader also features prominently in rapture theology. At the battle of Armageddon, the Left Behind narrative portrays Jesus impassively observing the "garroting and ripping open of the unbelievers" and raising his hand to direct a chasm to open in the earth. Once open, hordes of screaming unbelievers are swallowed up until the earth finally closes over, restoring calm across the landscape. God is described as rejecting unbelievers' repentance, having become impatient with their slow change of heart. As Jesus presides over the torture of unbelievers, God is portrayed as an impassive and merciless presence (Jones, 2008). These horrendous scenes can elicit a powerful affective response in readers. Will believers subsequently transpose that affect into daily life?

Considering this question, Jones observes that psychodynamic features of developmental psychology may account for the idealization of sacred authority by adherents of rapture theology. But will believers actually assume into themselves the badness that the Left Behind narratives describes and subsequently discharge it on demonized others they believe will be left behind in the apocalypse? Jones (2008) notes that, in the majority, adherents of American apocalyptic Christianity have not acted on features of their beliefs that establish the psychological preconditions for participation in religiously inspired violence. Jones cites two reasons: Believers in rapture theology hold that God will make the first move in the rapture; their duty is to wait. Moreover, most devotees are committed to converting others. They want their friends and neighbors saved, not left behind as purged refuse of a sinful world. Nevertheless, Jones (2008) notes that a belief system rooted in rapture theology, represented by groups such as the Army of God, the Christian Identity Movement, and the Christian Defense League, has penetrated other white supremacist and/or neo-Nazi groups that do have criminal records for violence, creating a worrisome situation that may portend more violence in the future.

Jones (2008) makes a psychology of religious humiliation central to his exploration of groups who participate in or are inclined toward religiously inspired violence. He argues that splitting (all-good and all-evil groupings) and belief in a punitive and wrathful deity function as sources of shame for members of these groups, inclining them toward violence and establishing a concern with purification. Humiliation has social and interpersonal features. Persons may experience group humiliation based on political, economic, and cultural factors. And their 
sacred texts and religious leaders may evoke feelings of personal humiliation when believers perceive that they do not measure up to the ideals expressed in the texts and embodied or promoted by their leaders; or, even when they try, they fail.

Two examples of humiliation demonstrate its range. Jones (2008) concurs with other scholars who link feelings of humiliation among Palestinians with a fundamentalist turn in Islam which suicide bombers take up and transform into violence. Intense feelings of victimization are represented in statements by Palestinians and their supporters that hold Israel accountable for land occupation and denial of human rights. Humiliation cycles into violence as feelings of shame are replaced by aggression toward those held responsible for the injustice that has been the original source of humiliation. In the case of Aum Shinriko, a new religious movement in Japan whose members carried out a sarin gas attack in the Tokyo subway system, killing twelve and injuring over 3000 , no social isolation or marginalization accounts for expressions of humiliation among members of the group. Rather, their leader, Shoko Asahara, subjected members of the group to humiliation. Extreme punishments contributed to a culture of internally directed violence that created a climate in which group members felt threatened and under siege (Jones, 2008). They did not attribute the source of their fear and anxiety to Asahara, who elicited from the group complete submission and powerful identification. With every increase in his demands, his followers reported that they felt closer to him. Idealization and submission joined in members' fealty to Asahara (Jones, 2008). Eventually, members sought relief from humiliation in rites of purification. These rites entailed shedding others' blood and produced the sacrificial scene in the Tokyo subway system.

Shame and humiliation are linked also with bodily disgust (Jones, 2008). Disgust shapes contempt for a decadent, godless society and aggression against it. Individuals may express this disgust in attitudes toward their bodies or those of others and engage in acts of bodily mortification. Or they may fixate on bodily impurities. Blood, an example of a polluting concern across many cultures, offers a focus for further analysis of Girard, Sacks, and Jones' distinct approaches to the issue of religiously inspired violence.

But for a brief exploration by Girard (1977) in Violence and the Sacred of blood as agent of purification in the face of a death-portending threat, Girard links the transforming power of blood solely with violence. Sacks too associates the sacred power of blood almost exclusively with sacrificial violence. ${ }^{[8]}$ By contrast, Jones (2008) distinguishes concerns about bodily pollution that feature in the pathological dualism of the groups he studies, including blood pollution, from visceral markers of aggression that feature in sacrificial violence. Pollution concerns, linked with themes of death and rebirth, bring to expression abhorrence for the West and for altered gender roles (feminism, emasculation, and homosexuality). Describing how suicide bombers portray their actions, Jones writes, «It is not a martial discourse of anger and revenge but rather a spiritual discourse of redemption and purification». The blood of martyrdom purifies and redeems, drawing the community of the righteous together. Blood cleanses them of shameful impurities, making possible union with God (Jones, 2008).

In focusing on the complex intertextuality of pollution, Jones offers a more nuanced account of the spilling of blood than do Sacks and Girard. That new ideas alone cannot win the peace is incontestable in the wake of Jones' efforts to highlight the role of affect and bodily experiences such as disgust in religiously inspired violence. Where Sacks and Girard have focused on sacrificial violence whose paradigmatic instance is the scapegoat, Jones understands also 
that rituals of bodily purification target a deadly pollution. Protective responses against pollution overlap with but cannot be collapsed into sacrificial violence deployed as scapegoating. Pathological dualism shapes the lives of martyrs who seek a bloody release from the bodily stigma of pollution, and it characterizes groups caught in the throes of mimetic rivalries for whom the sacrificial blood of scapegoats promises peace. The martyr and the scapegoat may be embodied in one individual, mingling the transforming blood of purification with the salvific blood of sacrifice. However, psychoanalysis, rather than mimetic theory, is best positioned to distinguish the distinct pathologies of dualism, delineating death from violence, pollution from sacrifice, and martyrdom from scapegoating.

That Girard and Sacks have distinct perspectives on martyrdom and scapegoating further illuminates the importance of adding a psychoanalytic perspective to any discussion of these two modes of religiously inspired violence. Significantly, Girard does not distinguish the martyr from the scapegoat. For him, a «martyr» is what persecutors' myths call a scapegoat (Girard, 2001). Stephen, a Christian martyr, is cited also an example of a «lynching». Reminding us that martyrs are «witnesses», Girard juxtaposes the persecutors' perspective on Stephen with that of the witness: The martyr imitates the sacrifice of Jesus which breaks apart the sacrificial mechanism that has attributed guilt to the victim (Girard, 2007, 1987). Sacks (2017) references martyrdom once. He does not to equate it with scapegoating, as has Girard, but with suicide. Sacks acknowledges that «martyrdom» means to "die for your faith». Asserting that suicide bombers' actions are murder, Sacks adds that, even on the suicide bombers' own terms, their claim to martyrdom violates the jurisprudence of Islam concerning suicide. Sacks (2017) is silent on the tradition of martyrdom across the centuries of Judaism. But Bruce Chilton (2008), in Abraham's Curse: The Roots of Violence in Judaism, Christianity, and Islam, explores at length martyrdom in Judaism. Interestingly, Chilton also draws on Girard in his work. That Sacks and Chilton compose narratives with identical goals -to explain the origins of religiously inspired violence in the Abrahamic faiths by appeal to mimetic theory- and have as their foci two different subjects, one a scapegoat and the other a martyr, I attribute to Girard's identification of the martyr with the scapegoat. For Girard, they are one being, alternately viewed from the perspective of the persecutor and the victim.

In making space for a martyr who is not a scapegoat, Jones invites more complex reflections on religiously inspired violence. In that regard, I find suggestive that Girard (1987), describing the method of execution to which Stephen was subjected -stoning-comments that stoning is reserved in Judaism «for the most impure of criminals.» If Stephen's death is not the sacrificial death of a scapegoat, but a rite of purification exerted against the body of an individual who not only humiliated his fellow Jews by besting them in argument but also exemplified the threat of impurity by preaching blasphemy, a way opens to situate the entire legacy of martyrdom in the Abrahamic faiths on a purification axis distinct from the sacrificial axis on which mimetic theory has focused up to now. In this way, psychoanalysis enhances our capacity to locate solutions to violence that speak to fears of deadly pollution and not only to threats of rivalrous violence.

Jones' focus on embodied features of pathological dualism helpfully augments Girard and Sacks, demonstrating the important contribution a psychodynamic exploration makes to the study of religiously inspired violence. Affective values central to Jones' study hold great significance for any efforts to offer a comprehensive analysis of religiously inspired violence. In drawing out psychodynamic features linked to religiously inspired violence -splitting, 
submission, shame, humiliation, pollution, disgust- Jones shows that Sacks' plan to deploy prophetic ideas and exemplary role models to counter religiously inspired violence must be balanced with an appeal to intertextual practices inclusive of affect and embodiment. We must not only think effectively about peace but also affectively engage prospects for peace.

Somewhat surprising, then, is Jones' sketch of alternatives to religiously inspired violence rooted in fundamentalism. Similar to Sacks, Jones (2008) emphasizes imaginative openness in religious thought, to the neglect of ritual and other symbolic actions. Jones suggests that an apophatic theology descriptive of an infinite and undefinable God can counter deadly dualism with life-supporting ambiguity. Like Sacks, Jones is more attuned to thoughts of peace that would counter violence than to embodied practices that might facilitate individuals' efforts to reshape violence as peace. In search of such practices, I turn to another boundary psychology that complements analyses of religiously inspired violence explored up to now but draws attention to embodied actions to which Girard, Sacks, and Jones are insufficiently attentive.

\section{Embodied practices that counter Religiously inSPIREd Violence}

In Unclean: Meditations on Purity, Hospitality, and Mortality (2011), psychologist Richard Beck appeals to Girard as he explores relationships between purification and violence. Beck considers rituals and symbolic actions that fall under three affective domains: the body, mortality, and community. Giving special attention to disgust psychology that illuminates how humans respond to threats within each affective domain, Beck also looks for rituals that neutralize disgust, thereby restoring individuals and communities to wholeness. Beck complements Jones' focus on embodied features of pathological dualism, further highlighting affect's role in stimulating religiously inspired violence even as Beck seeks out alternatives. As a consequence of his attention to healing rituals, Beck contributes to the goal of identifying intertextual practices that not only describe non-rivalrous relationships but also reposition our bodies to enact them.

Beck (2011) offers a three-part typology of disgust. With core disgust, revulsion focuses on oral incorporation and expulsion as well as on other openings through which fluids and other products enter and leave our bodies. Such monitoring is instantaneous. We don't resolve to gag; instead, we involuntarily gag. Animal-reminder disgust has a strong existential component, bringing humans face-to-face with death. We loath humans who exhibit disease or deformities, appear animal-like, or are otherwise vulnerable. Finally, sociomoral disgust viscerally attests to the failure of community. Immersed in relationships with others, we are repulsed by the behaviors of others about whom we issue judgments. Sociomoral disgust, grounded in pollution fears, also is endemic to scapegoating, to which Girard's theory has so powerfully attested.

Let's look more closely at these three disgust domains and their relation to religion. Core disgust, a fully somaticized form of disgust, attests to how blood becomes a primary generator of pollution that is a focus of spiritual discourses of redemption and features in purification rituals. Core disgust can be traced to infancy. Humans are at our most somaticized when we are infants. Thus, as Kristeva (1982) suggests, affect in core disgust has its origins in the ur-subject's passage from nature to culture as it struggles to map the boundaries of its own proper being. Along the nether edge of language, maternal and infant bodies are attracted to 
and repelled by each other in the coming and going of bodily fluids, including blood. Rituals framed around blood -bounding it off or using it to reverse the very pollution with which initially it has been associated- replicate the work of the ur-subject, locating its salvific powers in our earliest experiences as embodied beings. Whereas core disgust is fueled largely by a somatic response (e.g., gagging, nausea), animal-reminder disgust is fostered by self-conscious awareness and mediated by language. In this way, underlying disgust for persons, things, and experiences that we label profane are profound anxieties about human vulnerability and death (Beck, 2011). Through rituals and other symbolic actions, we separate ourselves from that which is taboo, bounding off threatening powers that we associate with our mortality and mark with our disgust. Such acts secure our standing on the side of life, saving us from potentially lethal pollution. In depicting sociomoral disgust, Beck notes that, during times of crisis, sociomoral disgust can «infect» an entire population (Beck, 2011). Monsters are prime agents of infection that attest to boundary confusion. They are hybrids. Crossing borders, monsters are animal and human, flying and lumbering beasts. Rituals that expel or eliminate monsters secure the community against that which has threatened its identity. These rites are Girard's focus when he reflects on scapegoating.

The disgust domains identified by Beck reveal humans in the act of creating identities with body-work grounded in affect. Disgust bounds off experiences and people perceived as threatening. It features in rites that promise purification from corruption already incurred and immunity against the threat of future invasion. Antisemitism, on which Sacks has focused attention in his analysis of religiously inspired violence, also is given attention by Girard. Girard (1986) offers an example: In Medieval England during the plague, Jews were persecuted as its presumed cause, in part because they had lower infection rates. ${ }^{[9]}$ However, because Jewish doctors were respected for their knowledge, they were summoned to treat anyone infected with the plague. Pollution fears tainted these relationships: if a Christian family who sent for a Jewish doctor on behalf of one of its members who had fallen ill failed to show sufficient respect to the doctor, he might infect additional family members with the plague; if the doctor was shown sufficient respect, he might cure the ailing individual. Thus, as a Jewish doctor came and went, contaminating threat and purifying power crossed back and forth across the threshold of the homes he visited, sustained by antisemitism. Periodically, stronger measures were taken to leverage control over Jews' liminal power to destroy and to heal: Jewish doctors, including Queen Elizabeth's physician, were executed; groups of Jews were massacred (Girard, 1986).

Beck's typology of disgust illuminates all features of this scenario. Core disgust is evident in the Black Death: victims of the plague experienced tissue bleeding that breached the surface of the body and blackened their skin. Animal reminder disgust features in depictions of Jews as monsters. Antisemitic images of Jews in the medieval age linked them with animals, especially the goat. In 1575, a German text depicted a Jewish woman giving birth to pigs (Girard, 1986). Sociomoral disgust is present in the breakdown of community. With homes and streets reeking from putrefying flesh, Jewish monsters beset communities decimated by the plague, fueling a virulent antisemitism that saw all three domains of disgust drawn into religiously inspired violence against Jews.

Animal reminder disgust proves especially illuminating of our efforts to connect Beck's typology with religiously inspired violence and actions that can counter it. Attending at length 
to the work that monsters do, Beck constructively augments Girard's theory of scapegoating, further illustrating why mimetic theory needs to be attentive to psychology and psychoanalysis. Beck takes from Girard the notion that the dynamics of the victimary mechanism stand exposed in the contemporary world. In the ancient world, the scapegoat was perceived to be guilty of the crimes of which it was accused. Disgust tracked that guilt. But scapegoating has become «morally transparent» in the modern world (Beck, 2011). We recognize a scapegoat as a blameless victim -indeed the very word «scapegoat» suggests to us that an innocent person has been accused of wrong doing rightly attributable to someone else. As a consequence, the mechanism of victimization no longer reliably functions to convert sociomoral disgust into sacrificial violence, bringing peace to a community after the person responsible for the unrest has been expelled or killed. But Beck elaborates on Girard with his attention to monsters. For Beck, scapegoats are innocent; monsters are malevolent. Differentiating monsters from scapegoats, Beck reserves the term «monster» for beings targeted still by the affective violence of disgust (Beck, 2011). Scapegoating once was the analogue of the vomit response in disgust; the scapegoat was powerfully ejected from society as a lethal contaminant. Today, only monsters maintain the power to disgust; moreover, only creatures who disgust us remain for us guilty parties deserving of mob violence.

In suggesting that monsters still lurk, not yet exposed by the scapegoat-busting eye, Beck sheds light on a key issue for understanding and countering religious violence. Throughout human history, identifying and expelling scapegoats has been the primary means by which communities have stopped run away violence. If, as Girard has claimed, scapegoats can no longer perform the sacred task of taking on violence, purifying it, and letting the community return to peace because we now know that scapegoats are innocent victims of persecution, violence can only escalate. But Beck (2011) suggests that effective intervention is still possible if we look for what disgusts us. Disgust feeds conflict; when we neutralize disgust, we starve violence. Perhaps in our present age the only successful interventions against religiously inspired violence can be those that target disgust.

What are remedies for disgust? Beck (2011) identifies three kinds of rituals that correspond with each of the three domains of disgust. Although rituals that breach body boundaries (e.g., eating, touching) can be placed in service to core disgust, they also can be invoked for different ends, eliciting from individuals feelings of harmonious accommodation to or even celebration of humans' passage from nature to culture, from vulnerable dependence to relational interdependence. Similarly, in the face of animal reminder disgust, rituals can be sought that facilitate acceptance of mortality and enhance our abilities to cope with our fear of death, providing an alternative to pollution-focused rituals. And rituals of hospitality can replace rituals of exclusion associated with sociomoral disgust.

Beck finds in the Gospel of Matthew (9:10-13) an example of a ritual that functions as an intervention in disgust. In the story, Jesus is challenged for eating with «tax collectors and sinners», socially marginalized individuals whose impurities elicit disgust. These individuals contaminate; if Jesus eats with them, opening his body to food they have touched, contamination will spread. The scene described in Matthew suggests that a boundary psychology of exclusion is in play. When Jesus invites to the table and eats with individuals previously excluded from fellowship, his gesture of hospitality is an intervention in sociomoral disgust. His actions also challenge core disgust (eating with persons we loath makes us nauseous) and animal reminder 
disgust (eating with persons who fall outside the boundaries we have set for full inclusion in our community appalls us). In the face of seemingly intractable conflict that has crystalized around table fellowship, Jesus responds affectively. More than anything Jesus says, when he breaks bread with people who are social outcasts and pariahs, he reverses the power of contagion. ${ }^{[10]}$ Compassion born of Jesus' gesture of hospitality disrupts the disgust psychology that has fueled conflict.

Beck notes how Jesus takes on contagion, stating 'I desire mercy, and not sacrifice'» (Matthew 9:13). With these words, Jesus delineates disgust from violence, pollution from sacrifice. The hospitality that Jesus commends to those who join him at the table is born of a desire for mercy. Beck links mercy with human vulnerability or neediness. Neediness is that aspect of each of us that is compromised: we are hungry, disabled, or ill. In the conflicts over table fellowship in Matthew, disgust enabled persons to hide from their own vulnerabilities. Jesus models an alternative vulnerability. If we can accept mercy from or offer it to someone, we can set aside false claims to wholeness and self-sufficiency. Freed to embrace physical, psychological, material flaws and vulnerabilities that otherwise would elicit our disgust, we can exercise hospitality. Disgust pushes contaminants outside the boundaries of community and erects ever higher walls to purify a community of contagion. By contrast, human vulnerability opens connections with others (Beck, 2011).

Sacks and Beck have both drawn on mimetic theory to inform their explorations of religiously inspired violence. As a consequence, that Beck's story of table fellowship in Matthew complements Sacks' story about Joseph and his brothers is not surprising. Together, these stories establish affective grounds for transformation that Sacks attributes to teshuvah and Beck to hospitality: when we stand in the shoes of our rivals, no longer exchanging roles of victim and victimizer in a never-ending cycle of retribution but embracing our rivals instead, we interrupt violence and establish conditions necessary for peace. Sacks has pointed to stories of faith, such as Joseph's, as a source of transformation, citing an intertextual arc that guides us forward, enhancing our sensitivity to scapegoating and providing us with an ethics of plenitude that can replace the ethics of scarcity that has characterized acquisitive desire. With the story of table fellowship in Matthew, Beck provides a counterpoint to Sacks that explains how we might engage that ethics with our whole being: the intertextuality of signifying practices that are tactile, acoustic, and kinesthetic make it possible for words to become deeds when disgust is exchanged for vulnerability and openness to the other. Demonstrating that humans are linked always to the embodied nexus of our origins and that affect plays a critical role in promoting as well as in challenging religiously inspired violence, Beck confirms the essential utility of psychoanalysis for mimetic theory already demonstrated by Jones. Beck and Jones point the way forward to further explore how psychoanalysis can function as a vital resource for mimetic theory.

\section{Bibliography}

Anspach, Mark. (2004). «Editor's Introduction». In Oedipus Unbound: Selected Writings on Rivalry and Desire. (Mark Anspach, Ed.). Palo Alto, CA: Stanford University Press.

Beck, R. (2011). Unclean: Meditations on Purity, Hospitality, and Mortality. Eugene, Or: Wipf \& Stock Publishers. 
Girard, R. (1965). Deceit, Desire, and the Novel: Self and Other in Literary Structure. Baltimore, MD: The Johns Hopkins University Press.

Girard, R. (1979). Violence and the Sacred. (Patrick Gregory, Trans.). Baltimore, MD: The Johns Hopkins University Press.

Girard, R. (1986). The Scapegoat. (Yvonne Freccero, Trans.). Baltimore, MD: The Johns Hopkins University Press.

Girard, R. (1987). Things Hidden since the Foundation of the World. (S. Bann \& M. Metteer, Trans.). Palo Alto, CA: Stanford University Press.

Girard, R. (2004). Oedipus Unbound: Selected Writings on Rivalry and Desire. (Mark Anspach, Ed.). Palo Alto, CA: Stanford University Press.

Girard, R. (2008). Mimesis and Theory: Essays on Literature and Criticism, 1953-2005. (R. Doran, Ed.). Stanford University Press.

Girard, R., Antonello, P., \& Rocha, J. C. de C. (2007). Evolution and Conversion: Dialogues on the Origins of Culture. New York, NY: Continuum.

Jones, J. (2008). Blood That Cries Out From the Earth: The Psychology of Religious Terrorism. Oxford University Press, USA.

Julia Kristeva. (1975). The Subject in Signifying Practice. Semiotext(E), 1(3), 19-34.

Kristeva, J. (1982). Powers of Horror: An Essay on Abjection. (L. Roudiez, Trans.). New York, NY: Columbia University Press.

Kristeva, J. (1984). Revolution in Poetic Language. (M. Waller, Trans.). New York, NY: Columbia University Press.

Martha J. Reineke. (2016). The Worm in the Pudding Cup: Violence, Disgust, and Mimetic Theory. Bulletin for the Study of Religion, 45(3-4), 34-45.

Naomi E. Pasachoff, \& Robert J. Littman. (2005). A Concise History of the Jewish People. Lanham, MD: Rowman \& Littlefield Publishers, Inc.

Sacks, J. (2017). Not in God's Name: Confronting Religious Violence (Reprint edition). Schocken.

\section{ENDNOTES}

[1] Sacks uses the terminology of myth in a Girardian manner. Rituals, according to Girard, empower societies to commemorate the sacrificial crises and manage future manifestations in ways that do not put them at risk. Whereas rituals function to replicate sacrifice in a controlled environment, myth records the reconciling work of violence. In myth, the victim is present as the passive and altogether guilty instrument of transformation, absolving the community that seeks to banish or kill it from charges of persecution (Girard, 1987).

[2] In The Scapegoat Girard observes that although every culture and person has a perception of those who are "different», attributions of difference are not trustworthy markers of potential victims. Others (e.g., the disabled, foreigners) are reproached «for not being as different as expected, and in the end for not differing at all». Prejudicial hatred «is expressed, not for difference, but for its absence» (Girard, 1986).

[3] Sacks does not cite Girard as an influence on his discussion of Joseph. However, Joseph is an important figure for Girard because describes the Joseph story as an initial exposure in human history 
of the scapegoat mechanism that reveals the innocence of the victim. Jesus will continue that exposure (Girard, Antonello, \& Rocha, 2007).

[4] The text says «arch» not «arc». Given the context, I believe that Sacks means «arc» (Sacks, 2017, p. 105).

[5] Relationships between parents and children traditionally have been primary examples of «external mediation". This form of mediation occurs when there is space between a desiring subject and its model large enough that they do not compete for the same object. Other role models, persons we admire and seek to emulate, also are examples of external mediation. By contrast, in internal mediation, the model and the subject who would imitate the model are perceived by the subject to share a world or situation. As a consequence, they become rivals when the subject attempts to acquire an object valued by the model (Girard, 1965).

[6] In Battling to the End, Girard (2009) also talks about Christ as model of external mediation. He describes «positive identification» and an «innermost» or «intimate» mediation which, experienced through the imitation of Christ, can transform mimeticism, opening the door to the other side of violence.

[7] Sacks' neglect of embodiment is surprising. Judaism is a religion of ritual through which individuals engage and respond to affective issues. The regulation of food into and out of the body and its amplification in the geography of the kitchen in kashrut, the purifying waters of the mikvah, family purity laws that shape the marital space and the rituals, the bounding of time throughout the day, etc. all make Judaism as much or more a religion of actions than of words. But Sacks emphasizes that, with the emergence of rabbinic Judaism after the destruction of the temple in $70 \mathrm{ce}$, the «wars of the lord» are fought not on the battlefield but in «the house of study. Judaism becomes a «culture of argument and debate, of words rather than weapons. Sacks loses sight of the other house of Judaism: the Jewish home and its proximate relation to the synagogue. Traversing between home and synagogue, Jews participate in an embodied, sacred geography through which the two houses are joined across space and time. Were Sacks to attend consistently to both houses of Jewish faith, he could consider the transformative potential of rituals that further empathy and compassion and counter rivalries of pathological dualism.

[8] «Impure» and «impurity» are words missing from Sacks' account. «Purification» is mentioned once, «purify» twice, and "pure» eight times. In only one of all these instances is purification linked with threatening bodily impurities, and that is with reference to the Nazi concern to purify Germany of the Jews who are «poisoning its bloodstream». Sacks' general use of the word «pure» is to mean «unalloyed» as in "purely local impact» (Sacks, 2017). Early in his career, Girard blood associated with sacrifice from blood associated with impurities, claiming that one is associated with violence and the other with death. However, he soon lost sight of this distinction and never again addressed pollution as a distinct issue in mimeticized violence. See (Reineke, 2016).

[9] Scholars attribute this relative immunity to the fact that Jews were compelled to live in isolation from Christians as well as to bathing hygiene associated with their ritual lives (Naomi E. Pasachoff \& Robert J. Littman, 2005).

[10] Pollution features dose insensitivity: even micro amounts of a contaminant are harmful. Pollution is also permanent; a polluted item, minus a rite of purification, cannot be rehabilitated. Negativity dominance also characterizes contagion of pollution. Research in experimental psychology shows 
that all power accrues on the side of a pollutant. If feces come in contact with food, a burger, for example, the burger is permanently polluted. The burger does not remove the contaminating power of the feces. Negativity dominates the positive in pollution. These characteristics of pollution account for why the presence of «sinners" at a table can generate powerful anxiety: even micro-levels of contact with the table and the food upon it can confer permanent pollution that contaminates every aspect of the repast (Beck, 2011). 